DOI 10.31558/2519-2949.2021.1.9

УДК 326:327.8:343.8:343.9

ORCID ID: https://orcid.org/0000-0002-2822-2268

Ягунов Д. В., Донецький національний університет імені Василя Стуса

\title{
КАТУВАННЯ ЯК ЕЛЕМЕНТ СОЦАЛЬНОГО КОНТРОЛЮ У ХХІ СТОЛІТТІ (ПОЛІТИЧНІ ТА ПРАВОВІ АСПЕКТИ)
}

\begin{abstract}
Стаття присвячена дослідженню феномену тортур у ХХІ столітті. У статті автор презентує тезу, що пояснює не лише відновлення тортур як феномену у другій половині ХХ століття, проте й на додаток - поширення цьього феномену тортур у ХХІ столітті, де особливого значення набувають питання щодо «розкидування» мереж соиіального контролю та, як наслідок, збільшення типів девіантів. Начіональні системи кримінальної юстичї не можуть впоратися з таким завданням - поводитися з девіантами виключно у рамках формальних процедур, закріплених у національному законодавстві на фоні збільшення типів та, як наслідок, кількості девіантів. У статті наголошується, що в суспільстві ХХІ століття тортури існують у рамках двох взаємопов'язаних політичних сфер, де однією зі сфер виступає формалізована суб'єктна політика протидї тортурам, яка формується та реалізується у рамках універсальних регіональних та національних структур, а другою сферою виступає безсуб 'єктна політика тортур, яка формується у рамках постсучасної модуляиії паноптичного менеджменту ризиків, де тортури $\epsilon$ інструментом сучасної політики соціального контролю. Піддаючи певній критичі інституційний та формально-інструментальний підходи до ідентифікації проблеми катування та нелюдського поводження у XXI столітті та вирімення иієї проблеми, зазначається, щзо зазначені підходи $є$ недостатніми у своєму автономному значенні. Домінування інституційного та інструментального підходів при формуванні та реалізаџї політики запобігання катуванням та набуття циими підходами монопольних ознак заздалегідь закладає проблему вже на початку відповідної стратегії. Катування - це проблема насамперед політична, і вирімення цієї проблеми потребує аналізу практики катувань як безсуб 'єктної політики з відповідними статистичними методами та показниками, які сьогодні майже відсутні як на міжснародному, так і на національних рівнях.

Ключові слова: глобалізачія, національна держава, катування, нелюдське поводження, Європейський суд з прав людини, Конвенція про захист прав людини, Рада Свропи, «посиленні методи допиту», запобігання катуванням, розслідування катувань, передумови катувань y XXI столітті.
\end{abstract}

Постановка проблеми у загальному вигляді та іï зв'язок із важливими науковими та практичними завданнями.

Проблема катування у XXI столітті набула додаткової актуальності з багатьох причин, які не можуть стояти осторонь уваги політиків, юристів, адміністраторів різних елементів національних систем кримінальної юстиції (у першу чергу - поліції та пенітенціарної системи). Проблема катування як політичного феномену актуалізується завдяки ширшому розкидуванню тонких мереж більш проникливого й технологічного соціального контролю та, як наслідок, збільшення типів девіантів та квазідевіантів, яких потрібно контролювати для цілей «убезпечення суспільства», що набуло статусу пріоритету політичного розвитку.

Національні системи кримінальної юстиції, будучи сферою політики, у ХХІ столітті зазнали ще більшого політичного впливу насамперед внаслідок занепаду велфаристської держави та супутніх традиційних (класичних) цілей соціального контролю, сформованих на початку XIX століття та пронесених крізь XX століття. При цьому подальшій, ще глибшій політизації національних систем кримінальної юстиції сприяє постмодерністська пунітивна культура соціального контроля.

На фоні ухвалення й подальшого запровадження масиву міжнародних та європейських стандартів прав людини та відповідних інституційних механізмів, активізації руху за обмеження ув'язнення та задекларованого повернення до неокласицизму у формальному обгрунтуванні цілей соціального контролю, у XXI столітті відбулася інтенсифікація карцеральної інтервенції, поступове приховане 
відновлення позитивістських засад кримінального судочинства та пенітенціарного менеджменту, що вказує на посилення соціального контролю через ще більше розчинення дисиипліни в суспільстві, однією зі складових чого виступають соціальні практики катування.

Сучасні держави, намагаючись запровадити у практичну діяльність поліції та інших органів правопорядку глобальні та регіональні стандарти прав людини, декларують максимальне дистанціювання від поліцейської держави (Polizeistaat), водночас не помічаючи наближення до стану паноптично-кариерної держави, функції якої зводяться до максимального соціального контролю населення шляхом широкого використання іiі інститутами практик ув'язнення, поширення неінституційних форм обмеження свободи громадян (у тому числі тих, які не пов'язані 3 кримінальною юстицією) та напрацювання практик цифрового контролю. Відповідно, більша інкарцерація суспільства не може не актуалізувати проблематику застосування неналежного поводження у практичній діяльності органів правопорядку та інших агентів держави.

Так, з одного боку, національні системи кримінальної юстиції не можуть впоратися зі складним завданням - поводитися з дедалі більшою кількістю девіантів і квазідевіантів виключно у рамках формальних процедур, закріплених у національному законодавстві та міжнародних стандартах прав людини. 3 іншого боку, існує нагальна потреба щодо дотримання формальних або неформальних планових показників з розкриття злочинів (чим характеризуються не лише країни пострадянського простору) з метою ще більшого задекларованого «убезпечення суспільства».

\section{Формулювання мети статті (постановка завдання).}

Враховуючи подане вище, у цій статті ми ставимо за мету: 1) проаналізувати катування як політичний феномен XXI століття; 2) ідентифікувати причини та умови, які сприяють відтворенню та поширенню соціальних практик катування у XXI столітті; 3) проаналізувати окремі показники соціальних практик катування; 4) запропонувати рекомендації щодо заходів, спрямованих на зменшення обсягів застосування катувань у діяльності агенцій кримінальної юстиції.

Аналіз останніх досліджень і публікацій, в яких започатковано розв'язання даної проблеми і на які спирається автор.

Проблематика боротьби з практиками катування знайшла своє відображення у дослідженнях таких вчених як В. Гацелюк, О. Гумін, В. Батчаєв, А. Замула, Є. Захаров, Д. Кобзін, М. Коваль, Р. Мигаль, О. Михайлик, М. Пузирьов, П. Пушкар, А. Савченко, Ю. Таволжанська, М. Хавронюк, А. Черноусов, С. Щербань та багатьох інших вчених. Проте зазначені питання здебільшого аналізувалися з погляду юридичної науки. Відповідно ця стаття є продовженням наукових розвідок автора, здійснених у контексті політичної науки $[1 ; 2 ; 9]$.

Виділення невирішених раніше частин загальної проблеми, котрим присвячується стаття.

Виділяючи невирішені раніше частини загальної проблеми, котрим присвячується стаття, ми постулюємо, що у XXI столітті політика запобігання катуванням та розслідування випадків катування - це відображення складного дуалістичного політичного прочесу: спроба ще більшого «убезпечення суспільства» з одночасним фіаско такого «убезпечення», коли ресурсів поліції та аналогічних за своєю природою агенцій кримінальної юстиції не вистачає на усі групи девіантів та квазідевіантів з їх численними представниками.

Катування стало об’єктивно невід'ємною складовою відносин влади та водночас побічним продуктом поширення паноптичної дисципліни. У сучасному суспільстві катування існує у рамках двох взаємопов'язаних політичних сфер, де однією зі сфер виступає формалізована суб'єктна політика протидї катуванням, що формується і реалізується у рамках універсальних регіональних та національних структур і механізмів, а другою сферою виступає безсуб'єктна політика катувань, яка формується у рамках постсучасної модуляції паноптичного менеджменту ризиків, де катування та нелюдське поводження $\epsilon$ інструментом сучасного соціального контролю [1;2].

Відповідно до викладеного вище ми формулюємо невирішену проблему: у XXI столітті соціальні практики катування аналізуються здебільшого як формально-юридична проблема, а відтак зазначена проблема - з погляду такого формального підходу - потребує насамперед інституиійних та інструментальних заходів, спрямованих на надання або уточнення формальних визначень тих або інших форм катування та жорсткого поводження, а також на підвищення результативності формальних процедур з розслідування зазначених дій.

Проте, як ми постулювали у наших попередніх дослідженнях, катування та нелюдське поводження у XXI столітті набули ознак безсуб'єктної політики (що не виключає за певних умов набувати суб'єктність) [2]. Відтак, у зазначеній системі координат використання інституційних механізмів та інструментальних засобів, спрямованих на задеклароване викорінення практики катувань та нелюдського поводження, поза межами політичного аналізу є недостатнім. 
Виклад основного матеріалу дослідження з повним обгрунтуванням отриманих результатів.

Вважається, що головним мотивом застосування катувань з боку агентів системи кримінальної юстиції є прагнення отримати докази, які можуть забезпечити винесення судом найсуворішого обвинувального вироку. Таким чином, системи кримінальної юстиції, які надмірно покладаються на самовикривальні показання як на доказ вини, створюють прямі стимули для застосування катувань, перш за все співробітниками поліції [3, с. 5].

Крім прямих стимулів, які сприяють поширенню практики катувань, у національних системах кримінального правосуддя існують чинники, що створюють сприятливі умови для застосування катувань. Зокрема, йдеться про надмірне використання тримання під вартою до підозрюваних та обвинувачених [3, с. 8]. Ризик застосування катувань та інших видів жорстокого поводження існує за різних обставин, але особливо він зростає тоді, коли підозрювані та обвинувачені утримуються під вартою на етапі досудового розслідування та судового розгляду [3, с. 11].

Так, за даними ООН на 2012 рік, на початку нового тисячоліття Америка та Свропа були регіонами $з$ найнижчими показниками «довирокового» ув'язнення (відповідно 21\% і 22\%). Водночас аналогічний показник для Азії та Африки перебував на рівні 40\% [4].

За даними ООН 2013 року, глобальна частка «довирокових» ув'язнених зменшилася $329 \%$ до $25 \%$ у період 2005 - 2011 років (з 61\% до 35\% в Африці, з 25\% до 24\% в Америці, з 18\% до 16\% у Свропі, залишаючись на рівні 42\% в Азіï) [5].

За даними ООН 2014 року, частка осіб, які перебувають у місцях попереднього ув'язнення, в світі зменшилася 3 30\% у 2004 році до 27\% у 2012 році. Найбільший прогрес виявився в Африці та Азії, де частка «довирокових» ув'язнених, зменшилася з 67\% до 57\% в Африці та з $52 \%$ до $47 \%$ в Азії. В інших регіонах це зменшення було менш помітним: в Америці - $325 \%$ до 24\%, в Свропі - $320 \%$ до $18 \%$ [6].

За даними ООН 2016 року, глобальна частка «довирокових» ув'язнених за період 2003 2005 років і за період 2012 - 2014 років скоротилася з 32\% до 30\%. У країнах Африки і Азії процентна частка «довирокових» ув'язнених істотно скоротилася (Африка - 38\%, Азія - 40\%), хоча цей показник по обом регіонам залишався високим. У країнах Свропи також було відзначено скорочення цього показника (з 20\% до 17\%), тоді як в країнах Америки та Океанії цей показник трохи збільшився (з 27\% до $29 \%$ та з $23 \%$ до $24 \%$ відповідно) [7].

Водночас фактором, що характеризує пенітенціарну політику України у XXI столітті, є поступове зростання кількості «довирокових» ув'язнених. За даними міжнародного дослідницького центру World Prison Brief, в Україні мала місце тенденція збільшення частки «довирокових» ув’язнених: 2000 рік - 20,4\%; 2006 рік - 20,6\%; 2007 рік - 20,5\%; 2010 рік - 25,7\%; 2013 рік - 21\%; 2014 рік 17,3\%; 2015 рік - 21,8\%; 2016 рік - 26,8\%; 2020 рік - 36\%. Отже, можна постулювати, що Україна заохочує поширення соціальних практик катування та нелюдського поводження через ширше використання попереднього ув'язнення.

Недостатність і недосконалість інструментального підходу в політиці запобігання катуванням та інших форм нелюдського поводження можна проілюструвати на наступному вітчизняному прикладі.

Так, серед міжнародних експертів існує консенсус щодо того, що ризик застосування катувань та інших видів жорстокого поводження є найбільшим безпосередньо після затримання [3, с. 16]. Щодо вітчизняної практики діяльності слідчих органів, то навіть якщо слідчий суддя згодом встановить у відповідній ухвалі про обрання запобіжного заходу більш-менш точний час затримання підозрюваного, будь-яких фактичних наслідків для слідчих та/або прокурорів встановлення такого факту не створює, що, у свою чергу, опосередковано стимулює поширення соціальних практик катування.

Крім того, у КПК України передбачено запобіжник, який - не можна цього не відзначити - багато в чому зменшує проблему катувань у практиці вітчизняних правоохоронних органів, адже існує прямий зв’ язок між практикою використання свідчень і кількістю випадків застосування нелюдського поводження [3, с. 16]. Йдеться про автоматичне визнання недопустимими доказів, отриманих внаслідок застосування катувань або нелюдського поводження (стаття 87 КПК України «Недопустимість доказів, отриманих внаслідок істотного порушення прав та свобод людини»). Так само, вирішенню проблеми сприяє закріплення в законі принципу безпосередності дослідження показань в суді (стаття 23 КПК України).

В українському контексті поєднання положень чинного КПК України та практики ССПЛ створює міцний фундамент для цілей виключення доказів, отриманих внаслідок застосування катувань, особливо беручи до уваги презумпцію: «Національні органи несуть відповідальність за ушкодження, 
якщо не доведуть того, що заявник був травмований до взяття його під варту, або не поясняють походження його травм» («Teslenko v. Ukraine», п. 89).

В Україні сьогодні зазначена практика ЄСПЛ набула поширення серед практикуючих юристів, що служить справі унеможливлення застосування нелюдського поводження: «Якщо встановлено, що особа потрапила під поліційну варту при доброму здоров’ї, але під час звільнення має тілесні ушкодження, на відповідну державу покладається обов'язок надати правдоподібне пояснення причин виникнення таких ушкоджень» («Bazorkina v. Russia», п. 104; «Bekos and Koutropoulos v. Greece», п. 47; «Bilyy จ. Ukraine», п. 65; «Kirpichenko v. Ukraine», п. 71; «Kobets v. Ukraine», п. 45; «Korobov v. Ukraine», п. 68; «Kovalchuk v. Ukraine», п. 59; «Lopatin and Medvedskiy v. Ukraine», п. 53; «Menesheva v. Russia», п. 52; «Mikiashvili v. Georgia», п. 69; «Ogorodnik v. Ukraine», п. 80; «Ribitsch v. Austria», п. 34; «Selmouni v. France» [GC], п. 87; «Süleyman Demir and Hasan Demir v. Turkey», п. 39; «Tomasi v. France», п.п. 108-111; «Zelenin v. Russia», п. 39; «Zhebrailova and Others v. Russia», п. 54).

За усталеною практикою ЄСПЛ, на державу покладається тягар доведення, згідно з яким вона має надати правдоподібне пояснення тілесних ушкоджень, яких зазнала особа під час перебування під контролем поліції («Buglov v. Ukraine», п. 71). Якщо якась особа дістає тілесні ушкодження під час перебування під вартою, коли вона повністю під контролем поліцейських, будь-яке ушкодження, отримане упродовж цього періоду, стає серйозним непрямим доказом («Bursuc v. Romania», п. 80; «Salman v. Turkey», п.п. 97-100).

Ще більшому використанню практики ЄСПЛ в Україні сприяє закріплення за рішеннями ЄСПЛ статусу джерела права (ст. ст. 8, 9 КПК України, ст. 17 Закону України «Про виконання рішень та застосування практики Свропейського суду з прав людини»).

Тим не менш, можна вказати на відсутність завершеності зазначеного запобіжника, адже головним фактичним стратегічним завданням будь-якого українського слідчого наразі залишається не постановлення обвинувального вироку за результатами розгляду судом обвинувального акту, а лише скерування обвинувального акту до суду, який був би - бажано - заснований на зізнавальних показаннях підозрюваного. Навіть якщо обвинувачений на підготовчому судовому засіданні заявляє про застосування до нього катувань та отримання його зізнавальних свідчень внаслідок застосування катувань, все одно обвинувальний акт зазвичай розглядається судом у звичайному режимі.

Проблему можна сформулювати наступним чином: кримінальна справа, в ході судового розгляду якої було виявлено явні ознаки застосування нелюдського поводження, здебільшого перетворюється на «вічну справу». Нерідко для судді стає більш доцільним «розтягувати» судовий розгляд на довгі роки, чому сприяє небажання багатьох суддів вступити у конфлікт із прокурорами. Навіть якщо обвинувачений через певний час (після спливу $3-4$ років після повідомлення про підозру) звернеться зі скаргою до ЄСПЛ щодо порушення розумних строків судового розгляду та навіть якщо виграє справу в ЄСПЛ, то державі простіше сплатити 1000 - 1500 євро за відповідним рішенням ЄСПЛ, аніж отримати виправдувальний вирок, пов'язаний з визнанням певних доказів недопустимими внаслідок застосування катувань або нелюдського поводження.

Водночас існує низка причин, за якими судді можуть демонструвати небажання виключити докази, отримані за допомогою катувань. Серед цих причин - небажання відмовитися від усталеного характеру здійснення правосуддя, зовнішне втручання до судового процесу або навіть можливість дисциплінарних санкцій щодо суддів, які виносять виправдувальні вироки.

Головним у цьому контексті $\epsilon$ те, що якщо навіть слідчий суддя (суд) з огляду на обгрунтовані твердження підозрюваного (обвинуваченого) призначить проведення судово-медичного обстеження останнього, а відповідні слідчі, які наділені повноваження здійснювати досудове розслідування випадків катувань, відкриють кримінальне провадження, то через відсутність ініціативи самого підозрюваного (обвинуваченого) перспективи досудового розслідування справи про катування $\epsilon$ сумнівними, особливо якщо жертва катувань перебуває у попередньому ув'язненні (що ще більше ускладняється відсутністю у нього адвоката як представника потерпілого). Тим самим нерідко порушується стандарт, встановлений ЄСПЛ: «Національні органи влади не повинні створювати враження, що вони готові залишити таке поводження безкарним» («Marguš v. Croatia» [GC], п. 126). Аналогічна теза знайшла своє відображення у звіті ОБСЄ: «У деяких випадках докази, отримані за допомогою катувань, визнаються допустимими не через помилки та недоліки у правових процедурах або низьку якість медичних висновків і судових експертиз, а тому, що судді просто не готові виключити ці докази» [3, с. 40].

Так само, в українському контексті можна також наголосити на зовнішньому тиску на прокурорів 3 метою засудження обвинуваченого, включно із застосуванням дисціплінарних заходів в разі постановлення виправдувального вироку [3, с. 41]. 
Говорячи про інструментальний підхід до вирішення проблематики катування та нелюдського поводження в країнах-членах Ради Європи, необхідно зазначити, що ЄСПЛ за багато десятиліть своєї діяльності сформував відповідні стандарти, які:

1) формують перелік дій, які підпадають під ознаки катування або нелюдського поводження («A. v. the UK», п. 21; «Z. and Others v. the UK» [GC], п.п. 11-36, 40, 74; «D.P. and J.C. v. the UK», п.п. 66-74; «Е. and Others v. the UK», п.п. 43, 89; «M.C. v. Bulgaria», п.п. 16-21, 30, 153; «Šečić v. Croatia», п.п. 8, 11, 51; «Nikolay Dimitrov v. Bulgaria», п.п. 9, 70; «Oleksandr Petrovych Kulakov v. Ukraine» (dec.); «Lorsé and Others v. the Netherlands», п. 63; «Sergey Savenko v. Ukraine», п. 36; «Aleksandr Nikonenko v. Ukraine», п.П. 6-9, 40; «Danilov v. Ukraine», п. 66; «Teslenko v. Ukraine», п.п. 101-102; «Aleksandr Smirnov v. Ukraine», п. 52; «Voykin and Others v. Ukraine», п. 103; «Skorokhodov v. Ukraine», п.п. 10, 30; «Gordiyenko v. Ukraine», п.п. 73-75; «Illhan v. Turkey» п.п. 73-78; «Kirpichenko v. Ukraine», п. 78; «Ogorodnik v. Ukraine», п. 76);

2) встановлюють умови недопустимості доказів, отриманих внаслідок застосування катування або нелюдського поводження («Othman (Abu Qatada) v. the UK», п. 264; «Gäfgen v. Germany» [GC], п. 166; «Tarasov v. Ukraine», п. 83; «Zyakun v. Ukraine», п. 39; «Harytyunyan v. Armenia», п. 63);

3) визначають принциипи розслідування катувань та інших форм нелюдського поводження ефективність, ретельність, оперативність, швидкість, незалежність («Denis Vasilyev v. Russia», п. 99; «Skorokhodov v. Ukraine», п. 32; «Biser Kostov v. Bulgaria», п. 77; «Gordiyenko v. Ukraine», п. 71; «Assenov and Others v. Bulgaria», п. 102; «Hovhannisyan v. Armenia», п. 51; «Mahmut Kaya v. Turkey», п. 86; «Milena Felicia Dumitrescu v. Romania», п. 52; «O’Keeffe v. Ireland» [GC], п. 172; «Yaşa v. Turkey», п. 98; «Labita v. Italy», п. 131).

Проте на фоні деталізації та роз'яснення стандартів і процедур проведення розслідування випадків катувань та інших форм нелюдського поводження ЄСПЛ запровадив дві категорії, які $€$ опосередкованим свідченням кризи інструментального підходу до вирішення проблеми катування та інших форм нелюдського поводження/покарання.

Так, ЄСПЛ на фоні широкого переліку стандартів та процедур ефективного розслідування катувань водночас наголошує, що аж ніяк не виключається нездатність держав ідентифікувати свої агентів, винних у злочинному насильстві щодо затриманої особи («Afanasyev v. Ukraine», п.п. 62-63; «Yaz v. Turkey», п. 30).

Крім того, на гостроту проблематики розслідування катувань у XXI столітті вказує те, що ЄСПЛ, незважаючи на чіткі принципи розслідування випадків катування та нелюдського поводження, запровадив категорію «саботування проведення розслідування» («Savitskyy v. Ukraine», п.п. 121-122; «Drozd v. Ukraine», п.п. 68-71; «Grinenko v. Ukraine», п. 62).

Крім того, ЄСПЛ окремо декларує, що на фоні усіх стандартів ефективного розслідування катувань абсолютно не виключаються випадки, коли держава не може притягнути до кримінальної відповідальності винуватців катувань у межах передбачених національним законодавством строків, внаслідок чого ЄСПЛ запровадив відповідний запобіжник: «Якщо представника держави було звинувачено у вчиненні злочинів, пов'язаних із застосуванням катувань або поганого поводження, $\epsilon$ дуже важливим, щоб проведенню кримінального провадження та винесенню вироку не перешкоджали строки давності, а амністії або помилування не застосовувалися» («Marguš v. Croatia» [GC], п. 126). Як наголосив ЄСПЛ, «зобов'язання держав переслідувати такі діяння, як катування та умисні вбивства, $є$ добре усталеним у практиці Суду. Практика Суду підтверджує, що застосування амністії щодо вбивства або поганого поводження з цивільними особами суперечитиме зобов'язанням держави за статтями 2 і 3 Конвенції, оскільки воно перешкоджатиме розслідуванню таких діянь і обов'язково створить ситуацію безкарності винних осіб. Такий результат зменшить вагу мети захисту, гарантованого статтями 2 і 3 Конвенції, та зробить ілюзорними гарантії щодо права особи на життя і права не піддаватися поганому поводженню. Об'єкт і мета Конвенції як інструменту захисту фізичних осіб вимагають, щоб її положення тлумачилися і застосовувалися таким чином, щоб iiï гарантії були практичними та ефективними» («Marguš v. Croatia» [GC], п. 127).

Оцінюючи недоліки інструментального підходу до ідентифікації та вирішення проблеми катувань та інших форм нелюдського поводження у XXI столітті, необхідно зробити наголос на наступному аспекті: ресурси правоохоронної системи мають важливе значення, проте їх наявність не виключає практику катувань. Навіть у тих юрисдикціях, де існують різні методи збору доказів та у слідчих є достатні ресурси, спостерігається використання таких методів ведення допиту, які можна розцінювати як катування або жорстоке поводження; одночасно існує тенденція до надмірного використання свідчень для винесення обвинувальних вироків [3, с. 24]. 
Як на нашу думку, проблема полягає у тому, що в сучасному суспільстві низка соціальних факторів роблять злочин анонімним: сучасна «масова злочинність» (злочини у сфері обігу наркотиків (крім зберігання), крадіжки, угони автомобілів тощо) характеризується низьким рівнем розкриття.

Як приклад можна навести окремі статистичні дані щодо розкриття злочинів в Англії, Уельсі, Шотландії, Північній Ірландії та Україні (таблиця 1, таблиця 2).

Табличя 1

Відсоток розкриття злочинів в окремих країнах (2002 - 2003)

\begin{tabular}{|l|c|c|c|}
\hline \multicolumn{1}{|c|}{$\begin{array}{c}\text { Показник розкриття злочинів, \% } \\
\text { (2002-2003) }\end{array}$} & $\begin{array}{c}\text { Англія та } \\
\text { Уельс }\end{array}$ & $\begin{array}{c}\text { Шотландія } \\
\text { Північна } \\
\text { Ірландія }\end{array}$ \\
\hline Незаконний обіг наркотиків & 93 & 99 & 68 \\
\hline Насильницькі злочини & 54 & 81 & 51 \\
\hline Статеві злочини (крім згвалтування) & 43 & 77 & 47 \\
\hline Згвалтування & 36 & 77 & 47 \\
\hline Шахрайство & 26 & 82 & 28 \\
\hline Розбійні напади & 18 & 38 & 13 \\
\hline Крадіжки та зберігання викрадених речей & 16 & 34 & 14 \\
\hline Викрадення транспортних засобів & 15 & 35 & 11 \\
\hline Викрадення речей з транспортних засобів & 6 & 18 & 3 \\
\hline Крадіжка із проникненням до приміщення & 12 & 26 & 10 \\
\hline Пошкодження майна & 13 & 22 & 13 \\
\hline Інші злочини & 69 & 99 & 40 \\
\hline Усі злочини & 24 & 46 & 23 \\
\hline
\end{tabular}

Таблиия 2

Відсоток розкриття злочинів в окремих країнах, \% $(2006,2008,2009)$

\begin{tabular}{|l|c|c|c|c|c|c|c|c|c|}
\hline \multirow{2}{*}{ Розкриття злочинів, \% } & \multicolumn{2}{|c|}{$\begin{array}{c}\text { Насильницькі } \\
\text { злочини }\end{array}$} & \multicolumn{2}{|c|}{ Статеві злочини } & \multicolumn{2}{c|}{ Розбійні напади } & \multicolumn{3}{|c|}{$\begin{array}{c}\text { Загальний } \\
\text { відоток }\end{array}$} \\
\cline { 2 - 12 } & $\mathbf{2 0 0 6}$ & $\mathbf{2 0 0 9}$ & $\mathbf{2 0 0 6}$ & $\mathbf{2 0 0 9}$ & $\mathbf{2 0 0 6}$ & $\mathbf{2 0 0 9}$ & $\mathbf{2 0 0 6}$ & $\mathbf{2 0 0 8}$ & $\mathbf{2 0 0 9}$ \\
\hline Англія & 53 & 47 & 35 & 39 & 18 & 21 & - & - & - \\
\hline Уельс & 66 & 56 & 66 & 56 & 33 & 34 & - & - & - \\
\hline Шотландія & - & 69 & - & 69 & - & 46 & - & - & - \\
\hline Північна Ірландія & 57 & 31 & 57 & 31 & 16 & 16 & - & - & - \\
\hline Україна & - & - & - & - & - & - & 67 & 71 & 64 \\
\hline
\end{tabular}

Зберігання наркотиків, як правило, має вищі показники розкриття, оскільки виявлення злочину та його розкриття зазвичай відбуваються одночасно. Показник розкриття цього виду злочину $\epsilon$ високим у більшості країн: 94\% - у Новій Зеландії, 99\% - у Республіці Ірландія (2009) [8, с. 20].

Рівень розкриття вбивств також, як правило, $є$ достатньо високим, через те, що системи кримінального правосуддя спрямовують більшість своїх зусиль на розслідування саме цих злочинів, а також через те, що більшість вбивств є побутовими [8, с. 20].

На відміну від цього, нижчим $є$ рівень розкриття таких злочинів, як крадіжки, грабежі та розбійні напади, де злочин, як правило, стає відомим лише через деякий час після його вчинення, коли злочинець покинув місце події.

Так, в Англії та Уельсі у 2010 - 2011 роках було розкрито лише 13\% крадіжок з проникненням до приміщення. У 2010 році в Шотландії було розкрито лише $25 \%$ крадіжок 3 проникненням до приміщення, у Новій Зеландії - лише $15 \%$ [8, с. 21].

Збільшення соиіальної мобільності є пропориійним послабленню соціальних зв'язків: сучасне урбанізоване та індустріалізоване суспільство характеризується тим, що люди знають один одного 
менше. Так само вони дедалі менше знають про власність один одного. Як наслідок, злочинцям набагато легше знаходити місця та території (за умови, якщо такі території та місця $є$ технологічно доступними для злочинців), де вони невідомі, так само як і місця збуту набутого злочинним шляхом майна. Анонімність цих злочинів призводить до низького рівня їх розкриття, що $є$ похідним від сутності сучасного суспільства та не завжди пов'язаним з недостатніми ресурсами поліції [9, с. 168]. Тому проблема зменшення обсягів соціальних практик катування безпосередньо пов'язана із дослідженням рівня розкриття злочинів та ефективністю діяльності поліції в цілому.

Так, подана нижче таблиця свідчить про відсутність суттєвого впливу цифрових технологій та науково-технічного прогресу на показники розкриття злочинів навіть у розвинутих країнах $[8$, с. 20] (таблиия 3).

Таблиия 3

Динаміка розкриття злочинів в окремих країнах, \% (2005 - 2009)

\begin{tabular}{|l|c|}
\hline \multicolumn{1}{|c|}{ Краӥна } & Динаміка рівня розкриття злочинів, \% (2005- 2009) \\
\hline Ірландія & $+5,6$ \\
\hline Франція & $+4,5$ \\
\hline Шотландія & $+3,6$ \\
\hline Англія та Уельс & $+0,6$ \\
\hline Каліфорнія & $+0,5$ \\
\hline Нова Зеландія & $+0,5$ \\
\hline Фінляндія & $-0,2$ \\
\hline Нідерланди & $-0,7$ \\
\hline Північна Ірландія & $-4,8$ \\
\hline
\end{tabular}

Крім того, необхідно вказати на тезу, яка спростовує поширене твердження, що збільшення кількості поліцейських обов'язково приводить до збільщення якості поліщейської роботи та, як наслідок, зменшення обсягів катувань та інших форм нелюдського поводження.

Беручи до уваги статистичні дані щодо кількості поліцейських на 100 тис. населення, можна дійти висновку, що у різних країнах, розташованих в одному географічному регіоні, кількість поліцейських може суттєво відрізнятися: Аргентина - 798 (2015), Перу - 330 (2009), Сальвадор - 335 (2012), Колумбія - 306 (2012).

У цьому контексті показовими є дані держав Північної Америки: Мексика - 464 поліцейських на 100 тис. населення (2012), США - 238 поліцейських (2018), Канада - 188 поліцейських (2017), які демонструють, що навіть удвічі більша кількість поліцейських у Мексиці, як порівняти із США, не рятує цю країну від поширення соціальних практик катування внаслідок контролювання значної частини території країни злочинними кланами та високої концентрації насильства у поліції та пенітенціарній системі. Водночас значно менша кількість поліцейських у Канаді, як порівняти із США, свідчить про те, що підтримання громадського порядку не обов'язково має супроводжуватися «насиченням» суспільства поліцією.

За даними ООН 2014 року, загальносвітовий показник кількості поліцейських на 100 тис. населення за період 2004 - 2012 років знизився з 305 до 297 [6]. На фоні сьогоднішнього загальносвітового показника (165 поліцейських на 100 тис. населення) різні країни демонструють абсолютно різні приклади: Ізраїль - 345 поліцейських на 100 тис. населення (2015), Японія 234 (2017), Нова Зеландія - 232 (2012), Південна Корея - 227 (2017), Австралія - 218 (2017), Бразилія - 211 (2014), Індія - 198 (2018), Китай - 143 (2018), що додатково підтверджує нашу гіпотезу.

Європейський досвід також свідчить про те, що наявність великої кількості поліцейських не може розглядатися як панацея від злочинності та поширення соціальних практик катувань. Водночас менша кількість поліцейських на душу населення також не зумовлює колапс правоохоронної системи з подальшим зверненням працівників поліції до практик катування з метою отримання зізнавальних показань.

Так, у 2012 році Чорногорія мала 677 поліцейських на 100 тис. населення, Сербія - 635, Іспанія 533, Туреччина - 524, Росія - 515, Греція - 513, Хорватія - 477, Італія - 456, Вірменія - 455, Португалія - 455, Мальта - 443.

Франція має 429 поліцейських на 100 тис. населення (2020), Словаччина - 403 (2019), Німеччина - 388 (2019), Чехія - 378 (2018), Угорщина - 366 (2015), Північна Ірландія - 362 (2015), 
Латвія - 357 (2012), Україна - 356 (2014), Австрія - 345 (2020), Болгарія - 339 (2015), Кіпр - 337 (2020), Естонія - 336 (2012), Бельгія - 333 (2017), Литва - 333 (2012), Албанія - 325 (2013), Білорусь 325 (2010), Шотландія - 318 (2014), Люксембург - 306 (2017), Андорра - 303 (2012), Румунія - 303 (2014), Нідерланди - 295 (2018), Ірландія - 265 (2012), Словенія - 264 (2017), Польща - 258 (2012), Ліхтенштейн - 241 (2012), Англія та Уельс - 211 (2019), Швейцарія - 210, Швеція - 197 (2019), Данія - 196 (2020), Ісландія - 196 (2016), Норвегія - 188 (2019), Фінляндія - 130 (2018) (таблиия 4, таблиия 5).

Табличя 4

Кількість поліцейських на 100 тис. населення та кількість рішень ССПЛ за статтею 3 Конвенції про захист прав людини $(1959-2020)$

\begin{tabular}{|c|c|c|c|c|c|}
\hline \multirow{2}{*}{ Краӥна } & \multicolumn{4}{|c|}{$\begin{array}{c}\text { Кількість поліцейських } \\
\text { на } 100 \text { тис. населення }\end{array}$} & \multirow{2}{*}{$\begin{array}{c}\text { Рішення ЕСПЛ } \\
\text { за ст. } 3 \text { Конвенції }\end{array}$} \\
\hline & 1997 & 2002 & 2007 & $2012-2020$ & \\
\hline Туреччина & 479 & 538 & 473 & 524 & 595 \\
\hline Румунія & 223 & 207 & 210 & 303 & 396 \\
\hline Греція & 411 & 470 & 458 & 503 & 133 \\
\hline Польща & 259 & 260 & 257 & 258 & 73 \\
\hline Італія & 459 & 488 & 552 & 456 & 56 \\
\hline Франція & 387 & 394 & 385 & 340 & 49 \\
\hline Угорщина & 287 & 285 & 262 & 366 & 43 \\
\hline Сполучене Королівство & 244 & 255 & 258 & 211 & 39 \\
\hline Литва & 406 & 336 & 330 & 333 & 36 \\
\hline Латвія & 453 & 438 & 360 & 357 & 32 \\
\hline Бельгія & 350 & 360 & 366 & 333 & 31 \\
\hline Хорватія & 510 & 440 & 460 & 477 & 27 \\
\hline Словенія & 343 & 371 & 396 & 264 & 27 \\
\hline Кіпр & 614 & 642 & 660 & 621 & 13 \\
\hline Іспанія & - & 464 & 483 & 533 & 13 \\
\hline Словаччина & 364 & 260 & 262 & 446 & 12 \\
\hline Нідерланди & 205 & 229 & 220 & 295 & 11 \\
\hline Естонія & 312 & 257 & 242 & 336 & 10 \\
\hline Німеччина & 280 & 300 & 304 & 381 & 6 \\
\hline Австрія & 330 & 345 & 321 & 314 & 5 \\
\hline Швеція & 190 & 181 & 196 & 195 & 5 \\
\hline Чехія & 242 & 446 & 248 & 378 & 4 \\
\hline Швейцарія & 201 & 208 & 224 & 210 & 3 \\
\hline Мальта & - & 455 & 454 & 443 & 3 \\
\hline Португалія & 441 & 465 & 488 & 445 & 2 \\
\hline Ірландія & 300 & 305 & 308 & 265 & 1 \\
\hline Данія & 186 & 191 & 195 & 192 & 1 \\
\hline Люксембург & 268 & 282 & 319 & 306 & 0 \\
\hline Ліхтенштейн & - & 236 & 264 & 241 & 0 \\
\hline Ісландія & - & 237 & 222 & 196 & 0 \\
\hline Норвегія & 187 & 182 & 160 & 188 & 0 \\
\hline Фінляндія & 153 & 159 & 155 & 130 & 0 \\
\hline
\end{tabular}


Середній показник кількості поліцейських на 100 тис. населення (2016 - 2018)

\begin{tabular}{|c|c|}
\hline & $\begin{array}{c}\text { Середня кількість поліцейських } \\
\text { на } 100 \text { тис. населення } \\
(2016-2018)\end{array}$ \\
\hline Чорногорія & 650,8 \\
\hline Кіпр & 576,0 \\
\hline Греція & 492,9 \\
\hline Хорватія & 491,0 \\
\hline Мальта & 487,1 \\
\hline Туреччина & 482,0 \\
\hline Косово & 470,0 \\
\hline Північна Македонія & 466,9 \\
\hline Італія & 452,7 \\
\hline Португалія & 450,4 \\
\hline Латвія & 423,5 \\
\hline Болгарія & 410,5 \\
\hline Словаччина & 404,5 \\
\hline Угорщина & 400,4 \\
\hline Чехія & 378,8 \\
\hline Албанія & 368,5 \\
\hline Північна Ірландія & 362,3 \\
\hline Іспанія & 361,4 \\
\hline Бельгія & 352,6 \\
\hline Словенія & 345,7 \\
\hline Австрія & 336,3 \\
\hline Франція & 328,2 \\
\hline Шотландія & 319,3 \\
\hline Люксембург & 316,6 \\
\hline Ліхтенштейн & 315,3 \\
\hline Німеччина & 297,3 \\
\hline Естонія & 296,6 \\
\hline Нідерланди & 295,6 \\
\hline Литва & 290,9 \\
\hline Польща & 261,1 \\
\hline Румунія & 246,9 \\
\hline Швейцарія & 218,3 \\
\hline Англія та Уельс & 211,8 \\
\hline Швеція & 199,6 \\
\hline Ісландія & 189,9 \\
\hline Данія & 188,5 \\
\hline Фінляндія & 137,8 \\
\hline Свропейський Союз (в цілому) & 340,4 \\
\hline
\end{tabular}


При цьому, в 2016 році у країнах Європейського Союзу нараховувалося 318 поліцейських на 100 тис. осіб, або один поліцейський на 314 осіб [10].



Рис 1. Середній показник кількості поліцейських на 100 тис. населення в окремих країнах (2016 - 2018)

Крім того, у 2016 році в країнах Європейського Союзу було 1,6 мільйона поліцейських, що на 3,4\% менше з 2009 року [10]. 
Загальна кількість поліщейських в країнах Європейського Союзу

\begin{tabular}{|c|c|c|}
\hline & $\begin{array}{c}\text { Загальна кількість поліцейських } \\
\text { в краӥнах Європейського Союзу }\end{array}$ & Крайни, які надали інформацію \\
\hline 1999 & 1509865 & 26 \\
\hline 2000 & 1523050 & 26 \\
\hline 2001 & 1517020 & 26 \\
\hline 2002 & 1519637 & 26 \\
\hline 2003 & 1499080 & 26 \\
\hline 2004 & 1508017 & 26 \\
\hline 2005 & 1519695 & 26 \\
\hline 2006 & 1535282 & 26 \\
\hline 2007 & 1536176 & 26 \\
\hline 2008 & 1413013 & 27 \\
\hline 2009 & 1518936 & 27 \\
\hline 2010 & 1497110 & 27 \\
\hline 2011 & 1494295 & 26 \\
\hline 2012 & 1491172 & 27 \\
\hline 2013 & 1485459 & 27 \\
\hline 2014 & 1507152 & 26 \\
\hline 2015 & 1500429 & 26 \\
\hline 2016 & 1508539 & 26 \\
\hline 2017 & 1513189 & 25 \\
\hline 2018 & 1517526 & 25 \\
\hline
\end{tabular}

Динаміка загальної кількості поліцейських у країнах Європейського Союзу представлена на поданому нижче графіку (таблиия 6, рисунок 2).

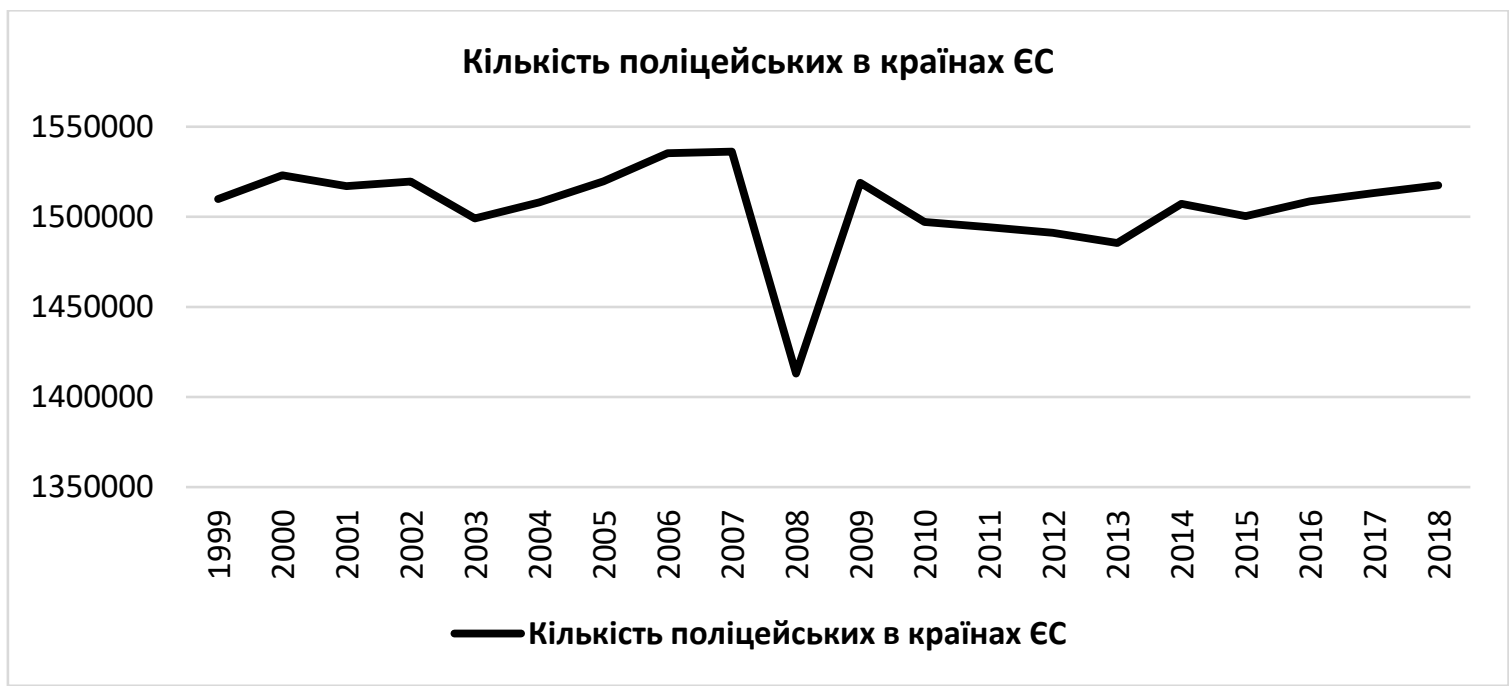

Рис 2. Динаміка кількості поліцейських в краӥнах СС (1999-2018) 
Щодо України, то кількість справ у ЄСПЛ за статтею 3 Конвенції з моменту набуття членства в Раді Свропи становить 381 (на фоні показника 356 поліцейських на 100 тис. населення).

Беручи до уваги держави, проти яких взагалі ЄСПЛ не ухвалював рішень за статтею 3 Конвенції (Люксембург, Ліхтенштейн, Швейцарія, Норвегія, Фінляндія) або за всю історію ухвалив не більше п'яти рішень за статтею 3 Конвенції (Австрія, Швеція, Чехія, Португалія, Ірландія, Данія), встановити залежність між відносними показниками кількості поліцейських та кількістю звернень до ЄСПЛ зі скаргами на катування (як у матеріальному, так процесуальному аспектах) не уявляється можливим (таблиия 7).

Табличя 7

\begin{abstract}
Кількість поліцейських на 100 тис. населення та країни з найбільшою кількістю рішень ССПЛ за статтею 3 Конвенції про захист прав людини (1959 - 2020)
\end{abstract}

\begin{tabular}{|l|c|c|}
\hline \multicolumn{1}{|c|}{ Краӥна } & $\begin{array}{c}\text { Поліцейські } \\
\text { на 100 тис. населення }\end{array}$ & $\begin{array}{c}\text { Рімення ССПл } \\
\text { за ст. 3 Конвениії }\end{array}$ \\
\hline Туреччина & 524 & 595 \\
\hline Румунія & 303 & 396 \\
\hline Україна & 381 & 356 \\
\hline Греція & 503 & 133 \\
\hline Польща & 258 & 73 \\
\hline Італія & 456 & 56 \\
\hline Франція & 340 & 49 \\
\hline Угорщина & 366 & 43 \\
\hline Сп. Королівство & 297 & 39 \\
\hline Литва & 333 & 36 \\
\hline Латвія & 357 & 32 \\
\hline Бельгія & 333 & 31 \\
\hline Хорватія & 477 & 27 \\
\hline Словенія & 264 & 27 \\
\hline Кіпр & 621 & 13 \\
\hline Іспанія & 533 & 13 \\
\hline Словаччина & 446 & 12 \\
\hline Нідерланди & 295 & 11 \\
\hline Естонія & 336 & 10 \\
\hline Німеччина & 381 & 6 \\
\hline
\end{tabular}

Так, приклад Німеччини, Кіпру, Іспанії та Словаччини з великою кількістю поліцейських на душу населення з надзвичайно низькими показниками звернень громадян до ЄСПЛ зі скаргами за статтею 3 Конвенції суперечить прикладам України, Румунії та Туреччини, які мають приблизно аналогічну кількість поліцейських на душу населення, проте водночас залишаються лідерами за кількістю скарг про катування та інші форми нелюдського поводження (рисунок 3).

Або, навпаки, приклади країн, які мають відносно невелику кількість рішень ЄСПЛ за статтею 3 Конвенції (Польща, Італія, Франція, Угорщина, Сполучене Королівство, Литва, Латвія, Бельгія) також характеризуються абсолютно різними показниками кількості поліцейських на 100 тис. населення (рисунок 4). 
Кількість поліцейських на 100 тис. населення та кількість рішень ЄСПЛ за статтею 3 Конвенції про захист прав людини

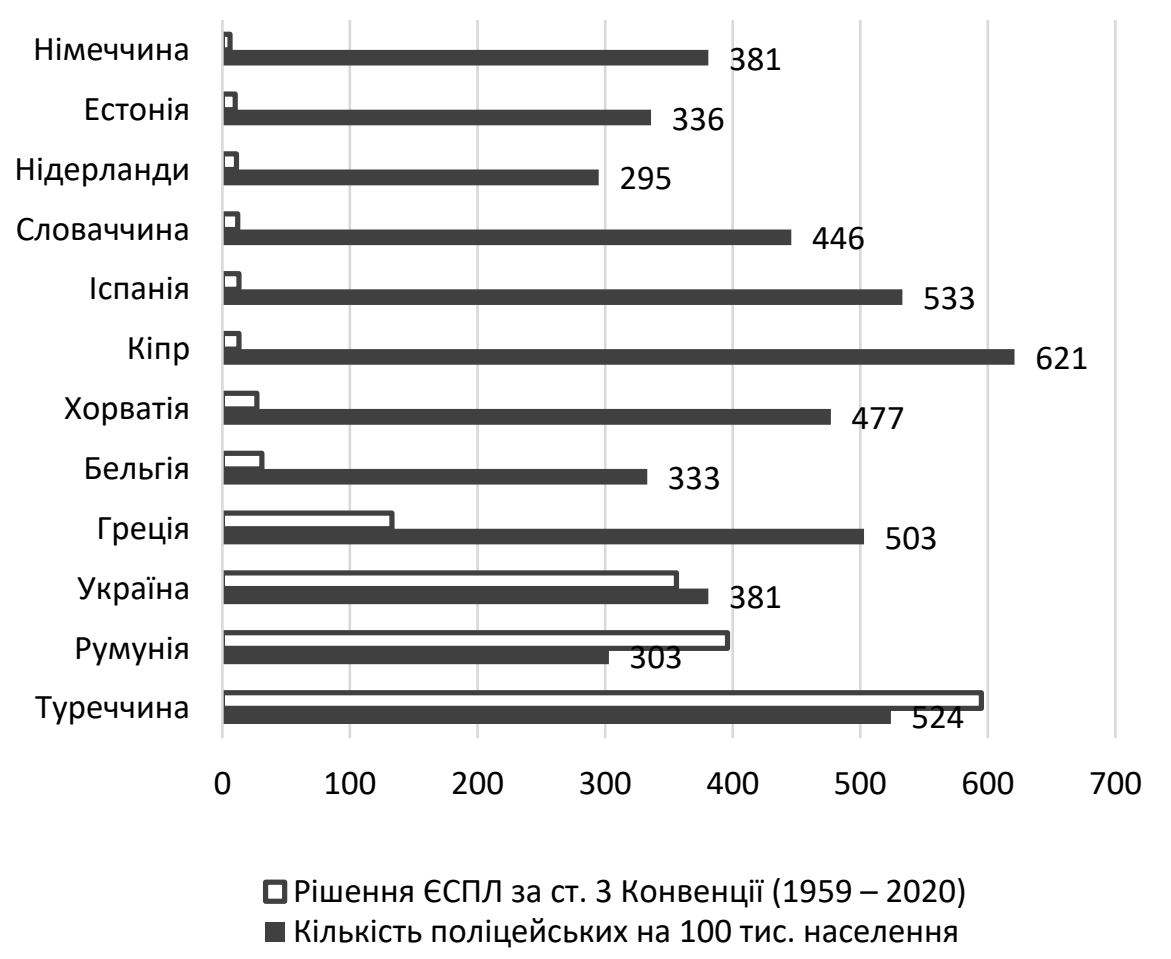

Рис 3. Кількість поліцейських на 100 тис. населення та кількість рішень ССПЛ за статтею 3 Конвенції про захист прав людини



Рис. 4. Кількість поліцейських на 100 тис. населення та кількість рішень ССПЛ за статтею 3 Конвенції про захист прав людини 
Щодо американської статистики, то ситуація є наступною.

На поданій нижче таблиці представлено дані щодо рейтингу 50-ти американських міст 3 найбільшою кількістю поліцейських на 100 тис населення та кореспондуючими показниками насильницьких злочинів і злочинів проти власності на 100 тис. населення [11].

Зокрема, у таблиці подано дані щодо 10 американських міст, які посідають найнижчі місця серед 50-ти лідерів, та щодо 10 американських міст, які посідають найвищі місця серед 50-ти лідерів (таблиия 8).

Таблиия 8

\section{Кількість поліцейських на 100 тис. населення у США та відносні показники злочинності}

\begin{tabular}{|l|c|c|c|}
\hline \multicolumn{1}{|c|}{ Місто, штат } & Поліцейські & $\begin{array}{c}\text { Насильницькі } \\
\text { злочини }\end{array}$ & $\begin{array}{c}\text { Злочини } \\
\text { протии власності }\end{array}$ \\
\hline Mount Vernon, New York & 390 & 510 & 1415 \\
\hline Boston, Massachusetts & 391 & 622 & 2016 \\
\hline Galveston, Texas & 393 & 521 & 3024 \\
\hline Charleston, West Virginia & 394 & 697 & 6010 \\
\hline Newport, Rhode Island & 394 & 342 & 2413 \\
\hline Biloxi, Mississippi & 397 & 323 & 5584 \\
\hline Memphis, Tennessee & 399 & 1943 & 6406 \\
\hline Atlanta, Georgia & 401 & 769 & 4654 \\
\hline East Orange, New Jersey & 404 & 515 & 1399 \\
\hline Laguna Beach, California & 405 & 388 & 1909 \\
\hline Portsmouth, New Hampshire & 408 & 163 & 5947 \\
\hline St. Louis, Missouri & 524 & 1800 & 2010 \\
\hline Newark, New Jersey & 528 & 733 & 7476 \\
\hline Miami Beach, Florida & 547 & 937 & 999 \\
\hline Camden County, New Jersey & 565 & 300 & 3086 \\
\hline Atlantic City, New Jersey & 585 & 721 & 1502 \\
\hline New York, New York & 613 & 541 & 5084 \\
\hline Beverly Hills, California & 622 & 307 & 4270 \\
\hline Washington, DC & 643 & 941 & 10547 \\
\hline Myrtle Beach, South Carolina & 968 & 1404 & \\
\hline
\end{tabular}

Проведений аналіз також надає підстави стверджувати про відсутність кореляції між відносними показниками кількості поліцейських та відносними показниками злочинності, що, у свою чергу, ще більше ставить під сумнів гіпотезу про залежність між насиченням суспільства поліцією, якістю роботи поліції та показниками неналежного поводження з боку агентів держави (рисунок 5).

На додаток, беручи за основу дослідження 2015 року, проведене The Guardian, доцільно порівняти США з окремими іншими країнами за показником кількості поліцейських на 100 тис. населення: США - 238 (2019), Канада - 188 (2017), Австралія - 218 (2017), Англія та Уельс - 211 (2019), Німеччина - 297 (2016) [12].

Із поданого вище випливає, що станом на 2015 рік США мали майже аналогічний показник, як порівняти з Канадою, Австралією, Англією та Уельсом. Водночас лідером за цим показником була Німеччина.

Проте за перші 24 дні 2015 року поліція США застосувала вогнепальну зброю з летальними наслідками проти 59 осіб. При цьому поліція Англії та Уельсу застосувала вогнепальну зброю 3 летальними наслідками проти 55 осіб за період 1990 - 2014 років [13].

Поліція США у 2015 році застосувала вогнепальну зброю з летальними наслідками проти 19 неозброєних афроамериканців (не враховуючи інші випадки), у той час коли поліція Німеччини за період 2010 - 2011 років застосувала вогнепальну зброю з летальними наслідками проти 15 осіб у цілому (як озброєних, так і беззбройних) [13]. 
Відносна кількість поліцейських та відності показники злочинності

Myrtle Beach, South Carolina

\author{
Washington, DC \\ Beverly Hills, California
}

New York, New York

Atlantic City, New Jersey

Newport, Rhode Island

Charleston, West Virginia

(1)

Galveston, Texas

Boston, Massachusetts

Mount Vernon, New York
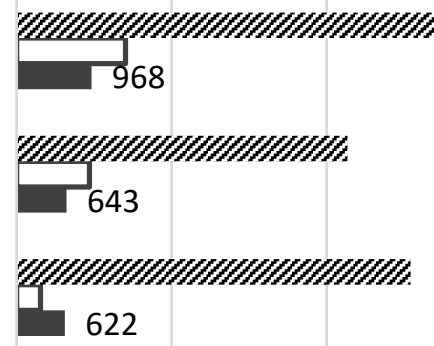

622

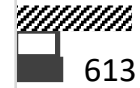

613


394
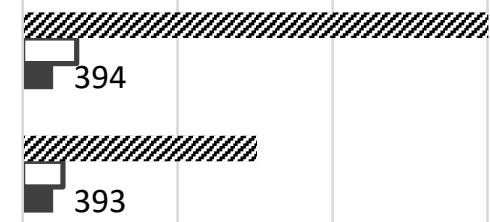

393

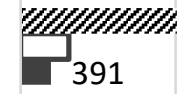

391



02000

$4000 \quad 6000$

$8000 \quad 10000$

12000

ஜ Злочини проти власності $\square$ Насильницькі злочини

\title{
Рис 5. Кількість поліцейських на 100 тис. населення та відносні показники злочинності у США
}

Поліція США лише за березень 2015 року застосувала вогнепальну зброю з летальними наслідками проти 97 осіб. Водночас за період 1992 - 2011 років поліція Австралії застосувала вогнепальну зброю з летальними наслідками проти 94 осіб [13].

Поліція Канади здійснювала у 2015 році в середньому 25 летальних пострілів на рік. Щодо США, то лише за 5 місяців 2015 року в штаті Каліфорнія (штаті, населення якого на $10 \%$ перевищує чисельність населення Канади) поліція здійснила 72 фатальні постріли [13].

Звичайно, йдеться не про катування за класичними визначеннями, сформульованими у міжнародних актах з прав людини. Йдеться про нерідко сумнівні дії поліції, які за своїми негативними наслідками навіть перевищують катування. Тому на фоні відсутності статистичних даних щодо катувань у різних країнах (особливо удинаміці) ці приклади беруться за основу дослідження, яке ставить під сумнів гіпотезу щодо залежності між кількістю поліцейських та використанням катування в діяльності поліції, а також доводить, що катування - це явище, яке має здебільшого політичну природу.

На окрему увагу заслуговує також і такий проблемний аспект політики протидії катуванням, як виконання планових показників у діяльності поліції та агенціях кримінальної юстиції аналогічної природи: «Не дивлячись на те, що більшість країн офіційно не використовують планові показники, 
багато хто з них насправді застосовують цей підхід на практиці. Там, де використання планових показників не закріплено в офіційній політиці або практиці чи навіть заборонено законом, вони нерідко використовуються на неформальному рівні» [3, с. 62].

Зазначена проблема нерідко розглядається як така, що $є$ більш характерною для країн пострадянського простору. Проте, як свідчить дослідження ОБСЄ, планові показники - це явище, характерне навіть для демократичних країн Західної Європи та Північної Америки $[14 ; 15 ; 16]$. Незважаючи на те, що в Англії та Уельсі планові показники роботи поліції були скасовані у 2010 році, аналіз, проведений у 2015 році, засвідчив, що на практиці вони все ще використовуються окремими поліцейськими службами [3, с. $68 ; 15]$.

Відтак ОБСє рекомендує скасувати планові показники роботи поліцейських служб щодо кількості арештів та обвинувальних вироків (основна увага при оцінці ефективності повинна приділятися попередженню правопорушень, задоволеності суспільства роботою поліції та рівнем довіри до поліції) [3, с. 68]. Також рекомендується скасувати планові показники для прокурорів, засновані на кількості обвинувальних вироків, і замінити їх якісними показниками (здатність подавати докази та клопотання, якість підтримання обвинувачення, здатність справлятися з робочим навантаженням тощо), а також соціальними характеристиками (шанобливе поводження зі підозрюваними, обвинуваченими, підсудними, свідками та потерпілими) [3, с. 68].

Крім того, говорячи про комплексну оцінку стан справ у сфері запобігання катуванням та засади формування відповідної політики, $\epsilon$ важливим наголосити, що наразі відсутня відправна точка. Так, йдеться про відсутність базової міжнародної, регіональної та національної статистики катувань в її динаміиі.

Висновки до даного дослідження і перспективи подальших розвідок у даному напрямку.

Підсумовуючи викладене вище та піддаючи певній критиці інституційний та інструментальний підходи до ідентифікації проблеми катування і нелюдського поводження у XXI столітті та вирішення цієї проблеми, ми, жодним чином не применшуючи їх цінність, постулюємо, що зазначені підходи $\epsilon$ недостатніми у своєму автономному статусі.

Домінування інституційного та інструментального підходів при формуванні та реалізації політики запобігання катуванням і набуття цими підходами монопольних ознак заздалегідь створює проблему вже на початку розроблення та реалізації відповідної стратегії. Катування - це проблема насамперед політична, і вирішення цієї проблеми потребує глибокого аналізу практики катувань як безсуб 'єктної політики з відповідними статистичними показниками, які сьогодні, як ми зазначили вище, майже відсутні як на міжнародному, так і на національних рівнях.

Так, $є$ велика кількість соціологічних досліджень 3 питань, чи відчувають громадяни страх бути підданим катуванням. Так само, $\epsilon$ велика кількість соціологічних досліджень 3 питань, чи виправдовують громадяни застосування катувань. Проте статистика самих катувань є майже відсутньою як на рівні окремих національних держав, так і на рівні міжнародних організацій, адже проблематика катувань здебільшого подається на рівні case study, що унеможливлює формування відповідної політики з протидії цьому політичному явищу.

\section{Бібліографічний список:}

1. Ягунов Д. Тортури як інструмент сучасної політики соціального контролю. Політичне життя, 2020. Вип. 4. С. 46-54.

2. Ягунов Д. «Malleus Maleficarum» of modern society: preconditions and prevalence of torture in XXI century and the policy of combating torture. Вісник Донецького наџіонального університету імені Василя Стуса. Серія Політичні науки, 2020. Вип. 5. С. 58-97.

3. Устранение стимулов применения пыток: Базовое исследование и практическое руководство для региона ОБСЕ. Варшава: Бюро ОБСЕ по демократическим институтам и правам человека (БДИПЧ) и организация «Fair Trials», 2020. C.16.

4. World crime trends and emerging issues and responses in the field of crime prevention and criminal justice. United Nations, Economic and Social Councilю Commission on Crime Prevention and Criminal Justice. Twenty-first session, Vienna, Vienna, 23-27 April 2012.

5. World crime trends and emerging issues and responses in the field of crime prevention and criminal justice. United Nations, Economic and Social Councilю Commission on Crime Prevention and Criminal Justice. Twentysecond session, Vienna, 22-26 April 2013.

6. World crime trends and emerging issues and responses in the field of crime prevention and criminal justice. United Nations, Economic and Social Council, Commission on Crime Prevention and Criminal Justice. Twenty-third session, Vienna, 12-16 April 2014.

7. Мировые тенденции в области преступности и новые проблемы в области предупреждения преступности и уголовного правосудия и способы их решения. Экономический и Социальный Совет ООН, 
Комиссия по предупреждению преступности и уголовному правосудию. Двадцать пятая сессия.

Вена, 23-27 мая 2016 года.

8. Comparing International Criminal Justice Systems. Briefing for the House of Commons Justice.

Committee Ministry of Justice. National Audit Office: SLS Print, February 2012. 51 p.

9. Ягунов Д. Пенітенціарна політика як складова соціального контролю. Одеса: Фенікс, 2020.

10. 1.6 million police officers in the EU. URL: https://ec.europa.eu/eurostat/web/products-eurostat-news/-/ DDN-20190104-1

11. Harrington J. Cities with the Most Police per Capita. URL: https://247wallst.com/specialreport/2020/06/24/cities-with-most-police-per-capita/

12. Vollzeitäquivalent der Beschäftigten im Aufgabenbereich Polizei in den Kern-haus-halten des Bundes und der Länder, 30. Juni 2019. URL: www.destatis.de/DE/Themen/Staat/Oeffentlicher-Dienst/Tabellen/beschaeftigtenpolizei.html

13. By the numbers: US police kill more in days than other countries do in years.

URL: www.theguardian.com/us-news/2015/jun/09/the-counted-police-killings-us-vs-other-countries

14. An N.Y.P.D. Sergeant Blows the Whistle on Quotas. URL: www.newyorker.com/podcast/political-scene/ an-nypd-sergeant-blows-the-whistle-on-quotas

15. Disgruntled cops say precinct ran arrest quota 'board game'.

URL: https://nypost.com/2015/03/31/disgruntled-cops-claim-precinct-ran-arrest-quota-board-game

16. Police reform: Theresa May's speech to the National Policing Conference Speech to the Association of Chief Police Officers and Association of Police Authorities National Conference on 29 June 2010, Manchester. URL: www.gov.uk/government/speeches/police-reform-theresa-mays-speech-to-the-national-policing-conference

\section{References:}

1. Yagunov D. Tortury yak instrument suchasnoi polityky sotsialnoho kontroliu. Politychne zhyttia, 2020. Vyp. 4. S. $46-54$.

2. Yagunov D. «Malleus Maleficarum» of modern society: preconditions and prevalence of torture in XXI century and the policy of combating torture. Visnyk Donetskoho natsionalnoho universytetu imeni Vasylia Stusa. Seriia Politychni nauky, 2020. Vyp. 5. S. 58-97.

3. Ustranenye stymulov prymenenyia putok: Bazovoe yssledovanye y praktycheskoe rukovodstvo dlia rehyona OBSE. Varshava: Biuro OBSE po demokratycheskym ynstytutam y pravam cheloveka (BDYPCh) y orhanyzatsyia «Fair Trials», 2020. S.16.

4. World crime trends and emerging issues and responses in the field of crime prevention and criminal justice. United Nations, Economic and Social Councilю Commission on Crime Prevention and Criminal Justice. Twenty-first session, Vienna, Vienna, 23-27 April 2012.

5. World crime trends and emerging issues and responses in the field of crime prevention and criminal justice. United Nations, Economic and Social Councilю Commission on Crime Prevention and Criminal Justice. Twentysecond session, Vienna, 22-26 April 2013.

6. World crime trends and emerging issues and responses in the field of crime prevention and criminal justice. United Nations, Economic and Social Council, Commission on Crime Prevention and Criminal Justice. Twenty-third session, Vienna, 12-16 April 2014.

7. Mirovyye tendentsii v oblasti prestupnosti i novyye problemy v oblasti preduprezhdeniya prestupnosti i ugolovnogo pravosudiya i sposoby ikh resheniya. Ekonomicheskiy i Sotsialnyy Sovet OON. Komissiya po preduprezhdeniyu prestupnosti i ugolovnomu pravosudiyu. Dvadtsat pyataya sessiya. Vena. 23-27 maya 2016 goda.

8. Comparing International Criminal Justice Systems. Briefing for the House of Commons Justice. Committee Ministry of Justice. National Audit Office: SLS Print, February 2012. 51 p.

9. Yagunov D. Penitentsiarna polityka yak skladova sotsialnoho kontroliu. Odesa: Feniks, 2020.

10. 1.6 million police officers in the EU. URL: https://ec.europa.eu/eurostat/web/products-eurostat-news/-/ DDN-20190104-1

11. Harrington J. Cities with the Most Police per Capita. URL: https://247wallst.com/special-report/2020/06/24/ cities-with-most-police-per-capita/

12. Vollzeitäquivalent der Beschäftigten im Aufgabenbereich Polizei in den Kern-haus-halten des Bundes und der Länder, 30. Juni 2019. URL: www.destatis.de/DE/Themen/Staat/Oeffentlicher-Dienst/Tabellen/beschaeftigtenpolizei.html

13. By the numbers: US police kill more in days than other countries do in years.

URL: www.theguardian.com/us-news/2015/jun/09/the-counted-police-killings-us-vs-other-countries

14. An N.Y.P.D. Sergeant Blows the Whistle on Quotas. URL: www.newyorker.com/podcast/political-scene/ an-nypd-sergeant-blows-the-whistle-on-quotas

15. Disgruntled cops say precinct ran arrest quota 'board game'.

URL: https://nypost.com/2015/03/31/disgruntled-cops-claim-precinct-ran-arrest-quota-board-game

16. Police reform: Theresa May's speech to the National Policing Conference Speech to the Association of Chief Police Officers and Association of Police Authorities National Conference on 29 June 2010, Manchester. URL: www.gov.uk/government/speeches/police-reform-theresa-mays-speech-to-the-national-policing-conference 
Yagunov D. V. Torture as an Element of Social Control in the 21st Century

(Political and Legal Aspects)

The paper is focused on research of the phenomenon of torture in the XXI century. In the paper,

the author presents a thesis that explains not only the resumption of torture as a phenomenon in the second half of the XX century but also spreading of the phenomenon of torture in the XXI century with corresponding dispersal of social control networks and, consequently, increasing of types of deviants. National criminal justice systems cannot cope with this task - to deal with deviants only within the formal procedures enshrined in national law against the background of increasing types and, consequently, the number of deviants. The article emphasizes that in the XXI century society torture exists within two interrelated political spheres, where the first of the spheres is a formalized policy of combating torture, which is shaped and implemented within universal regional and national structures. The second one is an informal torture policy, which is shaped within the framework of post-modern modulation of panoptic risk management, where torture is an instrument of modern social control. While criticizing the institutional and formal-instrumental approaches to the identification of the problem of torture and inhuman treatment in the XXI century and the solution of this problem, it is noted that these approaches are insufficient in their autonomous meaning. The dominance of institutional and instrumental approaches in the formation and implementation of policies of prevention of torture and the acquisition of monopoly characteristics by these approaches poses a problem in advance at the beginning of the strategy. Torture is primarily a political issue, and addressing it requires an analysis of the practice of torture as an impersonal policy with relevant statistical indicators that are now almost non-existent at both the international and national levels.

Keywords: globalization, nation state, torture, ill-treatment, European Court of Human Rights, European Convention on Human Rights, Council of Europe, enhanced techniques of interrogation, prevention of torture, investigation of torture, preconditions for torture in the XXI century. 